IRA-International Journal of Education \& Multidisciplinary Studies

ISSN 2455-2526; Vol.03, Issue 03 (2016)

Institute of Research Advances

http://research-advances.org/index.php/IJEMS

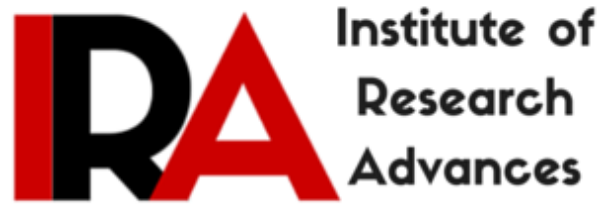

\title{
Students' Degree of Satisfaction of Student Services
}

Guiller P. Pendon

West Visayas State University- Janiuay Campus

Cabesa Jose D. Brana Street

Janiuay, Iloilo, Philippines.

DOI: http://dx.doi.org/10.21013/jems.v3.n3.p1

\section{How to cite this paper:}

Pendon, G. (2016). Students' Degree of Satisfaction of Student Services. IRA International Journal of Education and Multidisciplinary Studies (ISSN 24552526), 3(3). doi:http://dx.doi.org/10.21013/jems.v3.n3.p1

(C) Institute of Research Advances

\section{(cc) BY-NC}

This works is licensed under a Creative Commons Attribution-Non Commercial 4.0 International License subject to proper citation to the publication source of the work.

Disclaimer: The scholarly papers as reviewed and published by the Institute of Research Advances (IRA) are the views and opinions of their respective authors and are not the views or opinions of the IRA. The IRA disclaims of any harm or loss caused due to the published content to any party. 


\section{ABSTRACT}

The student services programs must provide an integral development among students manifested in institutional practices; thus, this descriptive study was undertaken to find out the students' degree of satisfaction of student services programs. A sample of 300 students of WVSU-Janiuay Campus were chosen through stratified-purposive sampling. The results showed that students were very satisfied of all student services. When classified as to sex and year level the respondents were very satisfied; however, when classified as to course only BEED were satisfied and other courses were very satisfied of all student services. No significant difference existed when respondents were classified as to sex and year level however there was a significant difference when respondents were classified as to course. Implications and recommendations for further research were discussed.

Keywords: Food service, guidance, health service, satisfaction, scholarships, sports and cultural, students, Student Affairs, student organizations student publication, student services programs.

Higher Education Institutions (HEI's) have become increasingly knowledgebased so that higher learning and research are essential to the cultural, socio-economic and environmental aspects of students' well being in order to promote sustainable development of college students. Higher education is therefore confronted with the challenge to make the most radical change in the delivery of student services programs. It must take the lead in moving the society from mere academic considerations to the deeper dimensions of the greater good for holistic development. In doing this, it must address social needs, promote solidarity and equity, preserve and exercise academic, nonacademic and scientific rigor, originality and impartiality (Hu, et.al, 2003).

Higher education must place students at the centre of its focus within a lifelong learning perspective so that they are fully integrated into the global knowledge society of the twenty-first century. Students must be considered as equal and fundamental partners and stakeholders in their own education with the right to be satisfied with the services received as they see fit within the context of their educational institutions, systems and communities (Pace, et al. 2006).

The student affairs and services are increasingly recognized as a division of importance in higher education. All functions in higher education must be properly managed, including student affairs and services. Effective management in student affairs and services includes the role of an overall manager for student services whose responsibilities are to provide co-ordination in developing functions and activities that enhance student learning and success within the context of a student services vision and mission (Arminio, 2009).

Student services must be delivered in a manner that is seamless, meaningful, and integrated with the academic mission of the institution. These practices and resulting policies must be built upon sound principles and research, and carried out by partnering with the entire campus community. Student affairs and services professionals are key players in turning the 'brain drain' into a 'brain gain' for all nations (Arminio, 2009).

The mission for student services must complement the institutional mission, its educational purposes, the locale in which it is operating, and its students' characteristics. 
Programs must be established and resources allocated for the purposes of meeting student services primary goals: enhancement of student learning and full development.

The delivery of student services is also based on a number of critical values including worth of the individual, diversity, pluralism, inclusiveness, community, high expectations, a global view, citizenship and leadership, ethical living, and the idea that students can and must participate actively in their growth and development (Greenlaw, 1997).

It may seem obvious that the most important knowledge required of staff working in the area of student services should be a thorough knowledge of the students with whom they work. Since students are the raison d'être for higher education, a thorough knowledge of the composition and characteristics (demographics) of the student population, the broad diversity, their expectations and satisfaction, their psychosocial physical development, as well as their behavior and motivation is crucial in ensuring the development and administration of the programs necessary to promote student success (Rhatigan, 2000).

In a word, student services staff members are required to be, or at least become (along with their faculty partners), the campus experts on knowledge and understanding about students and their development. Through careful analysis of existing data, the staff needs to develop a comprehensive and accurate assessment of students' expectation, identifying inadequate or missing information elements so that they can initiate appropriate action and inform campus administrators, faculty, student leaders, and government officials of the nature of the student body. Although work in this area readily gives staff a feel for students needs and wants - a sort of phenomenological understanding - it is crucial that scientific instruments and methods be used to supplement this view and provide a wider sociological perspective of the student body. (Shushok, 2010).

This study was anchored on adaptation-level theory, which is consistent with expectation and disconfirmation effects on satisfaction. This theory simply posits that the one perceives stimuli only in relation to an adapted standard. The standard is a function of perceptions of the stimulus itself, the context, and psychological and physiological characteristics of the organism. Once created, the 'adaptation level' serves to sustain subsequent evaluations in that positive and negative deviations will remain in the general vicinity of one's original position. Only large impacts on the adaptation level will change the final tone of the subject's evaluation (Akan, 1995).

The heart of the satisfaction process is the comparison of what was expected with the service's performance - this process has traditionally been described as the confirmation or disconfirmation process. First, customers would form expectations prior to availment of service. Second, consumption of or experience with the services produces a level of perceived quality that is influenced by expectations. If perceived performance is only slightly less than expected performance, assimilation will occur, perceived performance will be adjusted upward to equal expectations. If perceived performance lags expectations substantially, contrast will occur, and the shortfall in the perceived performance will be exaggerated

The West Visayas State University, specifically Janiuay Campus endeavors to provide quality student services by looking into consideration the holistic formation of all the students and by meeting their expectation. The student development programs and services will develop the full potential of individuals. These are being delivered by the offices under the Student Affairs. It must have promoted general welfare as a major concern because school is the student's second home. It is through the Office of Student Affairs (OSA) wherein students were encouraged to join in intra and extracurricular 
endeavors and gain comprehensive exposure \& training. The OSA also laid the groundwork for student leadership and responsible involvement.

The central focus of student services is to be with students, faculty and staff in accomplishing its goal in dealing with. Additionally, it must be cognizant to understand the growing diversity among student populations. Failure to seek out and nurture staff in the development of these people skills can have disastrous effects on the climate of any school (Baxter, 20013). In order to play a role in the growth process of individuals in higher learning institutions, the student services personnel need to interact on a one-onone basis with a wide spectrum of students. Whether the issues involve values clarification, career decisions or leadership development, health problems, a significant change usually comes on a personal level and student services staff members are ideally placed to positively influence this process both in individuals and in the larger context (Beodeker, 2006).

Currently, the OSA in West Visayas State University-Janiuay campus was delivering various student services; namely, student affairs, guidance, health, food service, sports and cultural, student publication, scholarships and student organizations; however, there was no tangible data to explain the students' degree of satisfaction of these services. The result of the study will be useful in determining the services to be improved and at the same time to meet the challenges set by the accreditation process.

This study aimed at ascertaining the degree of satisfaction of respondents of student services at West Visayas State University-Janiuay Campus for SY 2014-2015.

Specifically, this study sought answers to the following questions:

1. What is the degree of students' satisfaction of student services when taken as whole and classified according to sex, course and year level?

2. What is the degree of students' satisfaction of student services on student affairs, guidance, health services, sports and cultural, student publication, scholarship and student organizations when classified according to sex, course and year level?

3. Is there a significant difference in the students' degree of satisfaction of student services when classified according sex, course and year level?

\section{Procedure}

This study utilized the descriptive design to collect, analyze and classify data on degree of satisfaction of students on the student services namely student affairs, guidance, health services, sports and cultural, student publication, scholarship and student organizations when taken as a whole and classified according to sex, course and year level.

As initial step, the researcher identified the respondents during SY 2014-2015. Identification of student-respondents was based on their sex, course and year level.

The researcher constructed a rating scale designed to determine the degree of satisfaction of student services.

The tentative draft of the questionnaire was validated by a panel of jurors who were expert in the field of student services. After which, the questionnaire was revised and finalized then permission to conduct the study was secured from the campus administrator. The instrument was then distributed to students at West Visayas State University-Janiuay Campus. The researcher gathered the accomplished instruments as soon as the respondents finished answering them.

The data obtained from this investigation were tallied, computer processed, analyzed and interpreted. The answers of students in the degree of satisfaction of student services were used as the basis in improving the student services in the university. 


\section{Respondents}

Table 1

Profile of the Respondents as to Course, Sex and Year Level

\begin{tabular}{lcc}
\hline Categories & $\mathrm{f}$ & $\%$ \\
\hline Entire group & 300 & 100 \\
Sex & & \\
Male & 149 & 49.7 \\
Female & 151 & 50.3 \\
Course & & \\
BEED & 50 & 16.7 \\
BSED & 50 & 16.7 \\
BSInfoTech & 50 & 16.7 \\
BSHRST & 50 & 16.7 \\
BSIT & 50 & 16.7 \\
BCM & 50 & 16.7 \\
Year Level & & \\
First Year & & \\
Second Year & 75 & 25 \\
Third Year & 65 & 21.7 \\
Fourth Year & 65 & 31.6 \\
\hline
\end{tabular}

\section{Research Instrument}

The data-gathering instrument that was used in the study was a researcher-made questionnaire-checklist on the degree of satisfaction of student services.

The instrument consists of two (2) parts. Part One, requires of personal data such as name, sex, course and year level. Part Two is the instrument proper which was clustered to various student services, six(6) items for student affairs, four (4) items for guidance, three (3) for health services, one (1) for food service, six (6) for sports and cultural, four (4) for student publication, six (6) for scholarship and three (3) for student organization.

There were four levels to be determined, these were not satisfied, barely satisfied, satisfied and very satisfied.

"Not Satisfied" means that the respondents were not contented on student services programs and facilities.

"Barely Satisfied" means that the respondents have very little contentment on student services programs and facilities.

"Satisfied" means that the respondents have high contentment on student services programs and facilities.

"Very Satisfied" means that the respondents have highest contentment on student services programs and facilities.

Scale of Mean

$3.26-4.00$

$2.51-3.25$

$1.76-2.50$

$1.0-1.75$
Description

Very Satisfied

Satisfied

Barely Satisfied

Not Satisfied 
Table 2

\section{Findings}

Means and Standard Deviations on the Degree of Satisfaction of All Student Services when taken as Whole and classified According to Sex, Course and Year Level

\begin{tabular}{llll}
\hline Categories & Mean & SD & Description \\
\hline Entire group & 3.47 & .25 & Very Satisfied \\
Sex & & & \\
Male & 3.47 & .31 & Very Satisfied \\
Female & 3.47 & .27 & Very Satisfied \\
& & & \\
Course & & & \\
BEED & & .24 & Satisfied \\
BSED & 3.23 & .27 & Very Satisfied \\
BSInfoTech & 3.57 & .27 & Very Satisfied \\
BSHRST & 3.54 & .34 & Very Satisfied \\
BSIT & 3.50 & .21 & Very Satisfied \\
BCM & 3.53 & .26 & Very Satisfied \\
& 3.45 & & \\
Year Level & & & Very Satisfied \\
First Year & & .32 & Very Satisfied \\
Second Year & 3.48 & .29 & Very Satisfied \\
Third Year & 3.40 & .30 & Very Satisfied \\
Fourth Year & 3.49 & .24 & \\
& 3.50 & &
\end{tabular}

Table 3

Means and Standard Deviations on the Degree of Satisfaction of Students for All Student Services classified According to Sex

\begin{tabular}{llll}
\hline Categories & Mean & SD & Description \\
\hline Sex & & & \\
Male & & & \\
& & & \\
Student Affairs & 3.47 & .31 & Very Satisfied \\
Guidance Services & 3.21 & .25 & Satisfied \\
Health Services & 3.64 & .42 & Very Satisfied \\
Food Services & 3.69 & .53 & Very Satisfied \\
Sports and Cultural Services & 3.60 & .53 & Very Satisfied \\
Student Publication & 3.62 & .60 & Very Satisfied \\
Scholarship Services & 3.18 & .28 & Satisfied \\
Student Organization & 3.71 & .31 & Very Satisfied
\end{tabular}


Female

\begin{tabular}{llll} 
Student Affairs & 3.47 & .27 & Very Satisfied \\
Guidance Services & 3.29 & .22 & Very Satisfied \\
Health Services & 3.67 & .41 & Very Satisfied \\
Food Services & 3.72 & .45 & Very Satisfied \\
Sports and Cultural Services & 3.54 & .44 & Very Satisfied \\
Student Publication & 3.54 & .54 & Very Satisfied \\
Scholarship Services & 3.22 & .22 & Satisfied \\
Student Organization & 3.71 & .27 & Very Satisfied \\
\hline
\end{tabular}

Table 4

Means and Standard Deviations on the Degree of Satisfaction of Students for All Student Services Classified as to Course

\begin{tabular}{|c|c|c|c|}
\hline Categories & Mean & SD & Description \\
\hline \multicolumn{4}{|l|}{ Course } \\
\hline \multicolumn{4}{|l|}{ BEED } \\
\hline Student Affairs & 3.23 & .25 & Satisfied \\
\hline Guidance Services & 3.30 & .26 & Very Satisfied \\
\hline Health Services & 3.64 & .42 & Very Satisfied \\
\hline Food Services & 3.64 & .56 & Very Satisfied \\
\hline Sports and Cultural Services & 3.12 & .41 & Satisfied \\
\hline Student Publication & 3.87 & .46 & Very Satisfied \\
\hline Scholarship Services & 3.06 & .27 & Satisfied \\
\hline Student Organization & 3.64 & .28 & Very Satisfied \\
\hline \multicolumn{4}{|l|}{ BSED } \\
\hline Student Affairs & 3.57 & .27 & Very Satisfied \\
\hline Guidance Services & 3.30 & .23 & Very Satisfied \\
\hline Health Services & 3.67 & .40 & Very Satisfied \\
\hline Food Services & 3.74 & .49 & Very Satisfied \\
\hline Sports and Cultural Services & 3.74 & .49 & Very Satisfied \\
\hline Student Publication & 3.74 & .49 & Very Satisfied \\
\hline Scholarship Services & 3.25 & .22 & Satisfied \\
\hline Student Organization & 3.80 & .24 & Very Satisfied \\
\hline \multicolumn{4}{|l|}{ BSINFOTECH } \\
\hline Student Affairs & 3.54 & .27 & Very Satisfied \\
\hline Guidance Services & 3.30 & .16 & Very Satisfied \\
\hline Health Services & 3.65 & .49 & Very Satisfied \\
\hline Food Services & 3.68 & .47 & Very Satisfied \\
\hline Sports and Cultural Services & 3.68 & .47 & Satisfied \\
\hline Student Publication & 3.68 & .47 & Very Satisfied \\
\hline Scholarship Services & 3.32 & .15 & Very Satisfied \\
\hline Student Organization & 3.65 & .28 & Very Satisfied \\
\hline
\end{tabular}




\begin{tabular}{llll} 
BSHRST & & & \\
Student Affairs & 3.50 & .34 & Very Satisfied \\
Guidance Services & 3.20 & .21 & Satisfied \\
Health Services & 3.68 & .43 & Very Satisfied \\
Food Services & 3.66 & .52 & Very Satisfied \\
Sports and Cultural Services & 3.66 & .44 & Very Satisfied \\
Student Publication & 3.66 & .52 & Very Satisfied \\
Scholarship Services & 3.20 & .33 & Satisfied \\
Student Organization & 3.68 & .31 & Very Satisfied \\
& & & \\
BSIT & & & \\
Student Affairs & 3.54 & .22 & Very Satisfied \\
Guidance Services & 3.28 & .18 & Very Satisfied \\
Health Services & 3.58 & .26 & Very Satisfied \\
Food Services & 3.86 & .40 & Very Satisfied \\
Sports and Cultural Services & 3.66 & .35 & Very Satisfied \\
Student Publication & 3.84 & .41 & Very Satisfied \\
Scholarship Services & 3.23 & .25 & Satisfied \\
Student Organization & 3.86 & .20 & Very Satisfied \\
& & & \\
BCM & & & \\
Student Affairs & 3.45 & .26 & Very Satisfied \\
Guidance Services & 3.14 & .18 & Satisfied \\
Health Services & 3.63 & .40 & Very Satisfied \\
Food Services & 3.68 & .47 & Very Satisfied \\
Sports and Cultural Services & 3.55 & .41 & Very Satisfied \\
Student Publication & 3.68 & .47 & Very Satisfied \\
Scholarship Services & 3.17 & .21 & Satisfied \\
Student Organization & 3.63 & .26 & Very Satisfied \\
\hline
\end{tabular}

Table 5

Means and Standard Deviations on the Degree of Satisfaction of Students for all Student Services classified According to Year Level

$\begin{array}{llll}\text { Categories } & \text { Mean } & \text { SD } & \text { Description }\end{array}$

Year Level

First Year

Student Affairs

$\begin{array}{cc}3.48 & .33 \\ 3.25 & .25 \\ 3.60 & .43 \\ 3.69 & .52 \\ 3.61 & .53 \\ 3.65 & .58 \\ 3.22 & .32 \\ 3.68 & .29\end{array}$

Very Satisfied

Satisfied

Guidance Services

Health Services

Food Services

Student Publication

Scholarship Services

Very Satisfied

Very Satisfied

Very Satisfied

Very Satisfied

Student Organization

3.22

Satisfied

Very Satisfied 
Second Year

Student Affairs

$3.40 \quad .30$

$3.18 \quad .20$

$3.62 \quad .43$

Health Services

3.64

.51

Food Services

3.50

.55

Sports and Cultural Services

3.46

.66

Scholarship Services

3.12

.19

Student Organization

3.64

.31

Very Satisfied

Satisfied

Very Satisfied

Very Satisfied

Very Satisfied

Very Satisfied

Satisfied

Third Year

Student Affairs

$\begin{array}{ll}3.50 & .30\end{array}$

$3.36 \quad .18$

Very Satisfied

Guidance Services

$3.57 \quad .43$

Health Services

3.67

Sports and Cultural Services

3.58

Student Publication

3.58

Scholarship Services

3.24

.29

Student Organization

3.81

.21

Very Satisfied

Very Satisfied

Very Satisfied

Very Satisfied

Very Satisfied

Very Satisfied

Satisfied

Very Satisfied

Fourth Year

Student Affairs

$\begin{array}{ll}3.50 & .24\end{array}$

$\begin{array}{ll}3.23 & .19\end{array}$

$3.77 \quad .36$

.36

3.79

.41

3.57

.39

$3.60 \quad .49$

3.22

.20

3.72

.28

Very Satisfied

Satisfied

Very Satisfied

Very Satisfied

Very Satisfied

Very Satisfied

Satisfied

Very Satisfied

Table 6

Mann-Whitney Test result on the Degree of Satisfaction of Students for All Students Services When Respondents Were Classified According to Sex

\begin{tabular}{lllll}
\hline Categories & Mean Rank & Z & Asymp. Sig (2-tailed) & Statistical Decision \\
\hline $\begin{array}{l}\text { Sex } \\
\text { Male }\end{array}$ & 157.37 & & & \\
Female & & -.081 & .935 & Not Significant \\
\hline
\end{tabular}

$* p>.05$, Not Significant 
Table 7

One-Way ANOVA Test Result on the Degree of Satisfaction of Students for All Students Services When respondents were Classified According to Course

\begin{tabular}{lllllll}
\hline Categories & Sum of Squares & df & Mean Square & F & Sig. & Statistical Decision \\
\hline Between Groups & 3.79 & 5 & .757 & 10.316 & .000 & Significant \\
Within Groups & 21.58 & 294 & .073 & & & \\
Total & 25.369 & 299 & & & & \\
\hline
\end{tabular}

$* p<.05$, Significant

Table 8

Kruskal Wallis Test Result on the Degree of Satisfaction of All Student Services when classified According to Year Level

\begin{tabular}{lcccc}
\hline Categories & $d f$ & chi-sq & Asymp. Sig. & Statistical Decision \\
\hline Year Level & & & & \\
First Year & 3 & 7.092 & .069 & Not Significant \\
Second Year & & & & \\
Third Year & & & & \\
Fourth Year & & & & \\
\hline
\end{tabular}

$*_{p}>.05$, Not Significant

\section{Discussion}

When taken as a whole the respondents were very satisfied of student services and when classified as to sex, both sexes were very satisfied. Baxter, 2003, explained that equity in educational access of students of all groups and levels of the society is a foundation for success for higher education students services, thus, discrimination against and under-representation of these groups particularly on sex must be addressed immediately.

As to course the Bachelor in Secondary Education (BSED), Bachelor of Science in Information Technology (BSInfoTech), Bachelor of Science in Hotel and Restaurant Services Technology (BSHRST), Bachelor of Science in Industrial Technology (BSIT) and Bachelor in Caregiving Management (BCM) were very satisfied while only the Bachelor of Elementary Education (BEED) were satisfied. These results best explained the idea of Beodeker, 2006, which states that delivery of student services programs to students must be done in holistic fashion, treating the student as a whole person regardless of their field or course. This is in keeping with the idea student services program is for the purposes of enhancing life, developing employability in the appropriate level of the workforce, transmitting and improving culture and liberating the minds of the students to pursue liberty as responsible and intellectually curious citizens. The results also encompassed the idea of Colwell, 2006, which stated that the delivery of student services and programs is based on the number of critical values including worth of an individual, diversity, inclusiveness, community, high expectations, and the idea that the students can and must participate actively in their growth and development 
As to year level first year to fourth year respondents were very satisfied of student services. Highum, 2000 explained that the fundamental premise of providing pertinent and appropriate high impact, student centered services and programs, is an imperative that every student affairs personnel regardless of year level or degree was charged the tasks to acquire necessary knowledge and skills to carry it out in an effective manner.

As to the degree of satisfaction of students in the specific student services male respondents were satisfied of guidance and scholarship services while very satisfied of student affairs, health, food, sports and cultural, student publication and student organization services. Female respondents were satisfied of scholarship services and very satisfied of student affairs, guidance, health, food, sports and cultural, student publication and student organization.

All courses were very satisfied of student affairs services except the BEED who were satisfied. As to guidance services only the BSHRST and BCM were satisfied and all other courses were very satisfied. All courses were very satisfied of health, food, student publication and student organization services. Five (5) courses were very satisfied of sports and cultural services except the BEED who were satisfied. Only the BSInfoTech were very satisfied of the scholarship services and the rest of the courses were satisfied.

In the context of multicultural academic diversity, stimulated by globalization, it is necessary for all aspects of university life, student services included, to meet these new challenges. Many aspects of student life, on an academic, social or cultural level, become more difficult to understand and manage with a population that finds itself in a state of continual growth and diversification (Audin and Davy, 2003). To this effect, the creation of efficient student services that are focused on its necessities, in order to provide the required support for academic activity and stimulate personal, social, cultural and cognitive development, is needed.

All year levels were very satisfied of student affairs, health, food, sports and cultural, student publication, and student organization services. Only the $2^{\text {nd }}$ year was very satisfied of guidance services and all other year levels were satisfied. As to scholarship services all year levels were satisfied.

This is supported by the idea of Audin and Davy, 2003 that the role of these student services is influenced by the beliefs and values of the employed staff, by the manner in which the policies are elaborated, by the content of curriculum and services, and by the degree of knowledge regarding the development of the students and the way in which the environment outlines their behavior.

Mann-Whitney test showed no significant difference existed on the responses of respondents on the degree of satisfaction of student services when classified as to sex and also no significant difference existed when responses of respondents were classified as to year level using Kruskal Wallis test. One-Way ANOVA test result showed significant difference in the responses of respondents when classified as to course as indicated by the $.000 p$ value which is lower than .05 . This means that the knowledge of students, the delivery of student services and programs need to be crafted together in order to define, support and expand the mission of student services. The establishment of clear vision of student services programs is significantly important and designed to rally and focus efforts of the student services personnel and clientele, constitute the primary task of the individual responsible for OSA (Kezar, 2003).

\section{Conclusions}

In view of the findings, the following conclusions were deduced.

The study proved that students of West Visayas State University were contented of the student services. This showed that the goals of OSA complemented with the 
institutional vision, mission, goals and objectives (VMGO). The OSA must continually established programs and allocate resources to meet the students' needs and enhanced students' learning and development. It also explained that the WVSU-Janiuay OSA developed and adhered to high standards of practice and behavior. Students were very satisfied because they were engaged in their institution and in the learning process. This was done consistent with the principles of academic and personal integrity, responsible behavior and exercise of appropriate freedoms developed in the WVSUnian framework. From the responses of the students came the development of a strategy, techniques and models that will help make sense of that satisfaction in the student services to the diverse students.

It is therefore recommended that the West Visayas State University-Janiuay Campus must established a strategy with the intent of accomplishing its functions as follows:

The OSA at WVSU must continually establish, adopt, and disseminate unified and timely standards for student services, student development programs, academic support services and other related higher education programs and services.

The assessment and improvement of student services must be continued through self-study, monitoring and evaluation.

The head for student services must have looked into the scheme to increase scholarship grants to poor and academically deserving students and assume the primary responsibilities in providing coordination in developing functions and activities that will enhance success in student affairs services within the context of university's VMGO which may include appropriate resources and budget, regular assessment, evaluation and strategic planning, human resources, including professional development opportunities for student services personnel, partnerships with other areas of the institutions, technology infrastructure equity, information management and marketing of services and programs.

The OSA in WVSU must promote inter-division / inter-unit efforts to address student services issues to maintain quality assurance, student learning and professional integrity among universities.

Further researches must be conducted in order to widen the perspectives along this line. If possible, variables not being studied must be taken into account to make this study more comprehensive and other dimensions of other student services must also be explained by future researchers.

\section{References}

Akan, P. (1995). Dimensions of Service Quality: A Study in Istanbul. Managing Service Quality. 5(6): pp. 39-43.

Arminio, J., Roberts, D. C. \& Bonfiglio, R. (2009). The professionalization of student learning practice: An ethos of scholarship. About Campus. 14 (1), 16-20

Audin and Davy, 2003.K. Audin, J. Davy University quality of life and learning (UNiQoLL): an approach to student well-being, satisfaction and institutional change Journal of Further and Higher Education, 27 (4) (2003), pp. 365-382

Baxter Magolda, M.B. (2003). Identity and learning: Student affairs' role in transforming higher education. Journal of College Student Development. 44, 231-247

Beodeker, R. J. (2006). Faculty and student affairs collaboration: Factors that support and inhibit collaborative capacity. (Doctoral dissertaton, Columbia University, 2006)

Colwell, B. W. (2006). Partners in a community of learners: Student and Academic Affairs at small colleges. New Directions for Student Services, (116), 53-66 
Greenlaw, H.S., Anliker, M.E. \& Barker, S.J. (1997). Orientation: A student affairs or academic affairs function? NASPA Journak, 34, 303-312

Highum, AC., \& Lund, J.P. (2000). Partnerships in programming: Relationships that make a difference. In D.L. Liduell \& J.P. Lund (Eds.), New directions for student services (pp. 35-44). San Francisco: Jossey-Bass

Kezar, A. (2003). Enhancing innovative partnerships: Creating a change model for academic and student affairs collaboration. Innovative Higher Education, 28, $137-156$

Pace, D. Blumreich, K., \& Merkle, H. (2006). Increasing Collaboration between student and academic affairs: Application of the Intergroup model. NASPA Journal (National Association of Student Personnel Administrators, Inc. ), (43 (2), 301315

Shushok, F., \& Shiram, R. (2010). Exploring the effect of a residential academic affairs student affairs partnership: The first year of an engineering and computer science living-learning center. Journal of College and University Student Housing , 36 (2), 68-81 